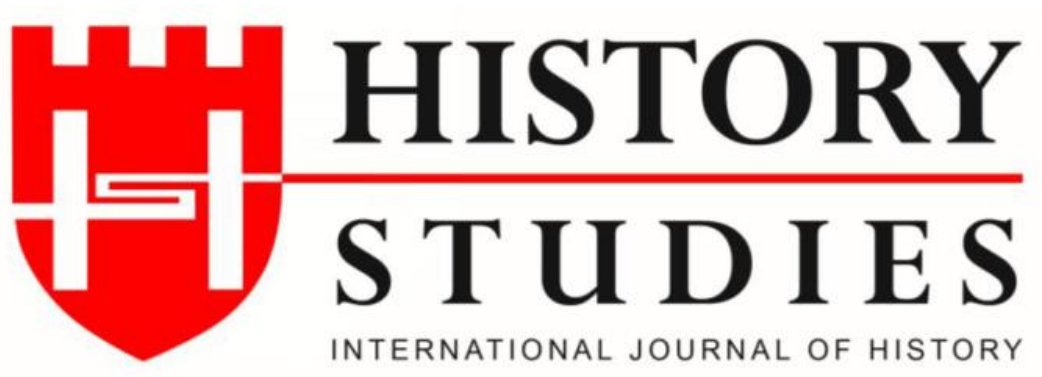

ISSN: 13094173 (Online) 1309 - 4688 (Print)

Volume 12 Issue 4, August 2020

DOI Number: 10.9737/hist.2020.886

Araştırma Makalesi

Makalenin Geliş Tarihi: 19.05.2020 Kabul Tarihi: 10.06.2020

Atıf Künyesi: Abdulhalik Bakır - Ebru Emine Oğuz, "The Polish-Lithuanian Union and Jadwiga the

Queen", History Studies, 12/4, Ağustos 2020, s. 1465-1480.

\title{
The Polish-Lithuanian Union and Jadwiga the Queen
}

\author{
Polonya-Litvanya Birliği ve Kraliçe Jadwiga
}

\author{
Prof. Dr. Abdulhalik Bakir - Ebru Emine Ŏguz \\ ORCID No: 0000-0002-4436-5322 / 0000-0002-1653-3325 \\ Bilecik Şeyh Edebali University
}

\begin{abstract}
Five hundred years of Piast Dynasty rule in the country was over with the death of Kazimierz III (Casimir the Great), one of the most prominent leaders of Poland. Since he did not have a son to replace after him, he bequeathed his throne to the child of his nephew who at that time was married to the king of Hungary. Thus, after Kazimierz III's death (1370) King Louis of Hungary ascended to the throne however Louis could not have any children. That's why he was forced to sign a treaty with the Polish nobles granting them privileges in order to be able to get her daughter Jadwiga to take the throne. So after that treaty she became Queen of Poland in 1384. As soon as Jadwiga became a queen, the Polish barons began to seek a husband to her, and they saw fit for Prince Jagiełlo of Lithuania. This marriage had a great importance for the future of the country. Because of the union that was formed between the two countries was a turning point for the history of Central and Eastern Europe due to changing the current political order. During that process the acreage of the Polish, Lithuanian and Ruthenian territories that combined with this manner had totally been reached to 800 thousand square kilometres. In our study, was prepared by using mainly foreign sources, through the first female leader of her country, in other words the 'king', was mentioned to the political and social life of Poland that became the most powerful state in the last quarter of the fourteenth century. In the final section of our paper, Queen Jadwiga's importance is referred through some American newspapers related to her who lived in fourteenth century as she was still mentioned after 600 years of her death.
\end{abstract}

Keywords: Poland, Lithuania, Jadwiga, Jagiełł, American press.

Öz: Polonya'nın önde gelen liderlerinden biri olan III. Kazimierz'in (Casimir the Great) ölümüyle (1370) birlikte ülkedeki beş yüz yıllık Piast Hanedanlığı hakimiyeti sona ermiş; ancak kendisinden sonra yerini bırakabileceği bir oğlu olmadığı için tahtını o dönem Macaristan kralı ile evli olan yeğeninin çocuğuna bırakmayı vasiyet etmiştir. Böylelikle III. Kazimierz'in ölümünün ardından Polonya tahtına Macaristan Kralı Louis geçmiş, fakat o da bir erkek evlat sahibi olamamıştır. Bu nedenle kızı Jadwiga'nın tahta geçmesini kabul ettirebilmek amacıyla Leh asillerine bazı imtiyazlar tanımak zorunda kalmış ve yapılan antlaşma sonrasında ise Jadwiga 1384 yılında Polonya kraliçesi ilan edilmiştir. Jadwiga kraliçe olur olmaz, ülkenin geleceği açısından Litvanya Prensi Jagiełło ile evlenmesi 
gündeme gelmiş ve bu sayede, mevcut siyasi düzeni değiştirmesi nedeniyle Orta ve Doğu Avrupa tarihi açısından adeta bir dönüm noktası teşkil eden Polonya-Litvanya birliği kurulmuştur. Böylelikle Polonya, Litvanya ve Rutenya topraklarının söz konusu süreçte toplam yüzölçümü 800 bin kilometrekareye ulaşmıştır. Yabancı kaynaklar kullanılarak hazırlanan bu çalışmamızda ülkesinin ilk kadın lideri, diğer bir deyişle 'kralı' olan Jadwiga'nın hayatı aracılığıyla ondördüncü yüzyılın son çeyreğinde Avrupa'nın en güçlü devletlerinden biri haline gelen Polonya'nın siyasi ve sosyal hayatına değinilmiştir. Makalemizin son bölümünde ise ölümünden 600 yıl sonra Amerikan basınındaki bazı gazete haberleri doğrultusunda, ondördüncü yüzyılda yaşamış olan Kraliçe Jadwiga'nın önemine yer verilmiştir.

Anahtar Kelimeler: Polonya, Litvanya, Jadwiga, Jagieło, Amerikan basını.

\section{Introduction}

At the end of 1370, the year of Casimir the Great's (Kazimierz III) death, there was, disunity and disorder state especially in the Eastern Europe. ${ }^{1}$ The effects of the Crusades had not finished yet. Because of the laxing of morality, crimes of violence stained the royal palaces and were committed openly through the streets. There was Moslem Ottomans opposing to the Christian world, they extended their sway over all the Moslems in Asia Minor and pushed toward the West. They transferred their military activities to South Eastern Europe. So in the second half of the fourteenth century, people of Poland and Hungary began to be the target groups of the Ottomans. ${ }^{2}$ The situation in the North Poland was also the same, the Teutonic Knights raised havoc and conquest of the peoples in what is now Prussia, Latvia and Lithuania. Furthermore the Tartar hordes raided and pillaged homes and properties of Polish people from the East. ${ }^{3}$ Although the religion dominated epoch, it was also the term of brutality and force. It was precisely during this period that the young Jadwiga was on the throne of Poland. ${ }^{4}$

King Casimir the Great left his throne to his nephew King Louis of Hungary. After the death of him in 1382 some nobles from Little Poland ${ }^{5}$ decided just twelve years of age Jadwiga to ascend to the Polish throne as King Louis had no male heir. Wars again divided the country into belligerent provinces, but the wisdom of the nation reasserted itself in the calling to the Kraków throne the young queen Jadwiga, who brought order and opened a new period of prosperity to her nation. ${ }^{6}$

Jadwiga formally crowned as a 'king' of Poland, but the main power would belong to her husband in the future. The Polish regency council overruled her family's plans for Jadwiga to marry Wilhelm of Habsburg Austria. So many factors dictated that decision, but the most crucial one was their common enemy Teutonic Knights of Prussia and Poland's idea to make a

\footnotetext{
${ }^{1}$ Sigismund John Sluszka, Queen Jadwiga in History and Legend, PhD Thesis, The Faculty of Arts of the University of Ottawa, Canada, 1950, p. 1.

${ }^{2}$ Sluszka, ibid, p. 3.

${ }^{3}$ Sluszka, ibid, p. 4.

${ }^{4}$ Sluszka, ibid, p. 7.

${ }^{5}$ Little Poland: Historic region and upland, hilly area in Southern Poland between Silesia, Mazovia, Podlasie, Ukraine and Slovakia, with the main cities of Kraków, Częstochowa, Sandomierz, Kielce and Lublin. (George Lerski, Historical Dictionary of Poland 966-1945, Greenwood Publishing Groups, Ed. Piotr Wróbel- Richard J. Kozicki, London 1996, p. 309).

${ }^{6}$ Sluszka, op. cit., p. 9.
} 
corporation with the only pagan country Lithuania. So far that purpose their marriage decision was an important step. ${ }^{7}$

\section{Jadwiga and the Polish-Lithuanian Union}

Jadwiga was born in 1374, 13 January and also grew up in Anjou ${ }^{8}$ that one of the most magnificent courts of Europe. ${ }^{9}$ She had two sisters. All of them were so important through their father's political plans ${ }^{10}$; according to those plans to betrothed Jadwiga to Wilhelm of Habsburg was appropriate. ${ }^{11}$ In 1378 Jadwiga met Prince Wilhelm during the journey with her family to Hainburg, a hill town on the border between Hungary and Austria and a very magnificent engagement ceremony took place. ${ }^{12}$ Though that looked unusual, families in the Middle Ages could often make these kinds of contracts for political and dynastical reasons. ${ }^{13}$ As in those days, the best way that had been found to keep peace between neighbouring countries was to promise their young princesses and princes in marriage to each other. So an agreement had bee signed by princes and elites of each countries, then the Pope in Rome had approved it. ${ }^{14}$
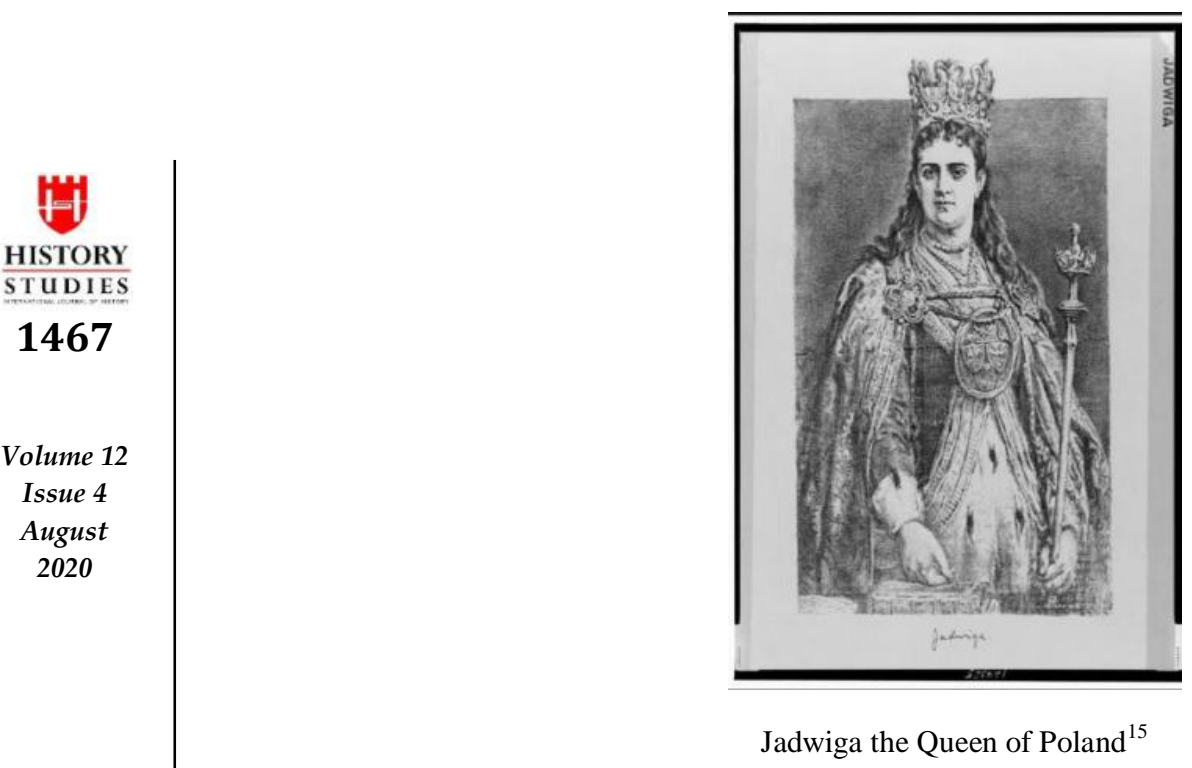

\footnotetext{
${ }^{7}$ Daniel Stone, The Polish-Lithuanian State, 1386-1795, A History of Central Europe, Vol. 4, University of Washington Press, Seattle and London 2001, p. 8.

8 Anjou: Term Angevin refers to the Anjou Dynasty of Geoffrey Plantagenet, the father of Henry II. (Hans Frede Nielsen, From Dialect to Standard: English in England 1154-1776, University Press of Southern Denmark, Denmark 2005, p. 1). This was an Anglo-French dynasty and deeply embedded in the complex structures of ruling families of Europe. (Michael Prestwich, Plantagenet England 12251360, Oxford University Press, New York 2005, p. 27).

${ }^{9}$ Sluszka, op. cit., p. 22.

${ }^{10}$ Sluszka, op. cit., p. 26.

${ }^{11}$ Sluszka, ibid, p. 27.

${ }^{12}$ Lois Mills, So Young Queen Jadwiga of Poland, Betlehem Books, Ignatius Press, Bathgate Lothrop, Lee and Shephard Co. Inc., 1961, p. 5.

${ }^{13}$ Sluszka, op, cit., p. 27.

${ }^{14}$ Mills, op. cit., p. 6.

15 Głos Polek, Vol III, Nov, 10, 1910, p,. 14, Library of Congress, www.tile.loc.gov/storage, A.D: 02.05.2020.
} 
As it was mentioned, Casimir the Great willed his throne to his nephew King Louis of Hungary's male children. That was why, Louis, who had no male heir, was trying to persuade the Polish nobles to have chosen one of his daughters as a queen. ${ }^{16}$ His efforts ended up positively and the Polish nobles accepted to choose his daughter Maria as their queen in return to the grants that had been recognized. But in 1382, just after Louis' immediate death, Maria was crowned as a queen of Hungary. For that reason she lost her chance to ascend to the Polish throne. So it was decided Jadwiga's ascending to the throne instead of Maria. ${ }^{17}$ Thus, Jadwiga, by crowning on 1384, 15 October, was the first woman that was taken the 'king' title. ${ }^{18}$ However she never named herself as a 'king' of Poland, in the chronicle accounts about her coronation addressed to her 'king' rather than 'queen'. ${ }^{19}$ Arguments over the kingship of Jadwiga are based on fourteenth and fifteenth century calender preserved in the Chapter of Kraków Cathedral. The texts which refer to her as 'king', do so only in some of their manuscript versions. Długosz, the most steadfast creation of Jadwiga myth to outweigh the pretensions of Jagiellonian rulers notes that she was crowned queen. ${ }^{20}$

The life and work of Jadwiga up to this period were but a preparation for the tremendous challenge of spirit that she was to face. The decisions that she was to render and the course of history of Poland and Christianity that she was to be focal point were just beginning to form. ${ }^{21}$ Since 1384, the day of her coronation, the question of being the 'chosen' one had been dwelled upon by the clergy, poets and historians. Even today, the question of Jadwiga as being the 'chosen one' is still fresh in the Polish and Christian world's mind. ${ }^{22}$

The elites of the country, who were looking for a husband to her just after a while of her coronation, decided her to get married with Prince Jagiełł of Lithuania. Furthermore Jadwiga’s mother Queen Elizabeth of Bosnia received repeated requests from Poland to send one of her daughters to be married to some prince of whom the Poles approve, who could take over and govern the country, for because of deteriorating situation the interregnum could not be permitted to continue. ${ }^{23}$ As with that marriage, by stopping the Lithuanian attacks, the rivalry on Ruthenian ${ }^{24}$ lands was ceased so that the chance about the economical developments of this country could be easily caught. But the most important one was the alliance against to their common enemy, Teutonic Knights, could be formed. ${ }^{25}$ Prince Jagiełło had the same idea just like Polish people that aforementioned alliance was the only way to resist them. By the way Jagiełło heard that Jadwiga had been brought from Hungary to Poland, crowned Queen of Poland and entrusted with full authority over all Poland and knowing her exceptional beauty, he sent a deputation, carrying the royal consent, to Jadwiga related to that issue, but she still

\footnotetext{
${ }^{16}$ Sluszka, op. cit., p. 40.

${ }^{17}$ Sluszka, ibid, p. 43.

18 Sluszka, ibid, p. 73.

19 S. C. Rowell, "The Marriage of Jogaila and Jadwiga Embodies, The Union of Lithuania and Poland", Lithuanian Historical Studies, Source Publications, p. 140.

${ }^{20}$ Rowell, op. cit., p. 140-141.

${ }^{21}$ Sluszka, op. cit., p. 87.

${ }^{22}$ Sluszka, ibid, p. 88.

23 Jan Długosz, Roczniki Czyli Kroniki Sławnego Krćlestwa Polskiego 1370-1405, Księga 10, Wydawnictwo Naukowe Pwn, Warszawa 2009, p. 153.

${ }^{24}$ Ruthenia: It is also known as White Russia, The country which is in Eastern Europe once belonged to U.S.S.R. Its capital city is Minsk. (The Ukranian Quarterly, Vol. 5, Ukranian Congress Committee of America, United States of America 1949, p. 67).

${ }^{25}$ Anna Kowalska Pietrzak, "History of Poland During the Middle Ages", Institute of History University of Łódź, Poland 2015, p. 78.
} 
intended to marry Wilhelm. ${ }^{26}$ In spite of her intention, an agreement was made between the princes of Poland and Lithuania concerning with Jagiełło's kingship by marrying Jadwiga on $1385^{27}, 14$ August in Krewo. ${ }^{28}$ According to that agreement, he, with all his subjects, would accept Catholic faith; he would give back the Polish lands that he conquered and they would all be considered Polish ones. ${ }^{29}$

1. Jagiello promised to free all Christian captives;

2. He proposed that they should form an indissoluble union of the kingdom of Poland and all territories subjected to Lithuania and Samogitia ${ }^{30}$, together with some Ruthenian land conquered by force of arms;

3. He further promised to recover and reincorporate into Poland territories of Pomerania ${ }^{31}$, Chełm $^{32}$, Silesia ${ }^{33}$, Dobrzyń ${ }^{34}$ and Wielun and all other territories surrendered, appropriated or wrested from the Kingdom;

4. His brother would bring to Poland all his treasure and that inherited from his father and grandfather and employ it for the benefit of Poland;

5. He promised to repay to Prince Wilhelm of Austria his surety of 20.000 Florins. $^{35}$

Volume 12

Issue 4

August

2020
${ }^{26}$ Długosz, op. cit., p. 188.

${ }^{27}$ Charlatte Kellogg, Jadwiga, Poland's Great Queen, Borodino Books, 2018, p. 11.

${ }^{28}$ Sluszka, op. cit., p. 113. Krewo Union: A marriage agreement, between Jadwiga and Jagiełł, signed at Krewo on August 14, 1385. Jagiełło did not simply offer a personal union between Poland and Lithuania, instead he made the sparse but historic promise to join (applicare) his lands of Lithuania and Russia perpetually to the Crown of Poland. He also pledged to baptize Lithuania, free Polish prisoners of previous wars, recover lands taken from Poland, pay Wilhelm for the breaking of betrothal and unify Poland and Lithuania (Lerski, op. cit., p. 277)

${ }^{29}$ Daniel Stone,The Polish-Lithuanian State 1386-1795, A History of Central Europe, Vol. 4, University of Washington Press, Seattle and London 2001, p. 8.

${ }^{30}$ Samogitia: Western part of Lithuania between Latvia, the Baltic Sea, the Niemen River and the Dubysa River This upland region with a narrow lowland stretching along the Baltic Sea is a cradle of Lithuanian statehood and played a crucial role during the wars with the Teutonic Knights (Lerski, op. cit., p. 694).

${ }^{31}$ Pomerania: Its meaning is people living by the sea (Pomorze: in Polish) (Norman Davies, God's Playground, A History of Poland, The Origins to 1795, Vol. 1, Columbia University Press, New York 2005, p. 27)

${ }^{32}$ Chełm: Town in the eastern part of Lublin region. In the mid-fourteenth century Chełm was briefly under Lithuanian and Hungarian rule, but in 1387, it was incorporated into Poland as a royal town (Lerski, op. cit., p. 63).

33 Silesia: A historical territory in Central Europe. For further information See. Albert Scholz, Silesia Yesterday and Today, Springer-Science, Business and Media B. V., Netherlands 1964, p. 2)

34 Dobrzyń: Town on the high bank of the Lower Vistula where Konrad of Mazovia founded the crusading of Dobrzyń Brethren (Militis Cristi de Prussia related to the Cistercians) in 1228 to protect the land from Prussian pagans. In 1240, the Dobrzyń Brethren were absorbed by the Teutonic Knights (Lerski, op. cit., p. 116-117).

${ }^{35}$ Długosz, op. cit., p. 189. 


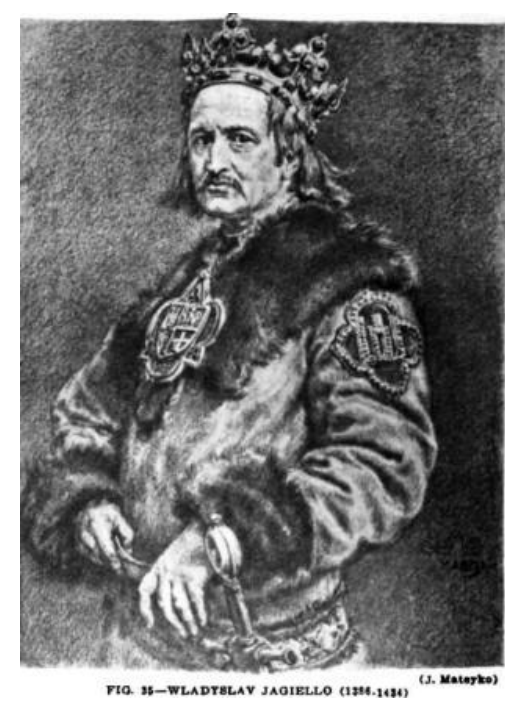

Jagiełło the Grand Duke of Lithuania ${ }^{36}$

Queen Elizabeth's reply was that she would allow whatever was advantageous to Poland and insists that her daughter and the prelates and nobles of the Kingdom had to do what they considered would benefit Christianity and their Kingdom. Envoys were at once sent to Lithuania to obtain conformation of these promises and bring Jagiello to Kraków to marry the Queen and rule over Poland. ${ }^{37}$ On February 12, 1386, the Grand Duke of Lithuania, Jagiełło, entered Kraków as the chosen husband of Jadwiga and therefore the king of Poland was baptized in the cathedral on February 15, 1386 and get his Christian name 'Władysław (in Polish) or Ladislus' ${ }^{38}$ Three days after his baptism, on February 18, Queen Jadwiga (13) and Jagieło (37) were married in the cathedral. ${ }^{39}$

Because of changing all the current political orders this marriage was a turning point for the East Central European history. Thus, the acreage of those unified countries, from Baltic Sea ${ }^{40}$ to Black Sea, from Odra ${ }^{41}$ and Dnieper ${ }^{42}$ rivers to Dvina ${ }^{43}$ river totally became to an area of 800.000 kilometres per square. ${ }^{44}$ But their common enemy, Teutons, by pointing out that the

${ }^{36}$ Edward H. Lewinski-Corwin, The Political History of Poland phD, The Polish Book Importing Company, New York 1917, p. 70.

${ }^{37}$ Długosz, ibid, p. 190.

${ }^{38}$ Sluszka, ibid, p. 167.

${ }^{39}$ Sluszka, op. cit., p. 169-170. To unwind the breaking of the betrothal with Wilhelm of Austria, as the custom demanded, took place, All matters of the infant marriage were settled and all ecclesiastical requirements were satisfied as mentioned above. All obstacles were removed.

40 Baltic Sea: Eastern branch of the North Sea, with Poland's three-hundred mile-long Pomeranian coastline extending from the mouth of Oder (Odra) River and the port of Szczecin to the mouth of the Vistula River and the Gulf of Gdańsk (Lerski, op. cit., p. 24).

${ }^{41}$ Odra (Oder): The second largest Polish river and one of the major rivers of Northern Europe. It flows 854 kilometres from its source in the Oder mountains in the Czech Republic (Lerski, ibid, p. 398).

${ }^{42}$ Dnieper: After Volga and Danube it is the third longest river in Europe. It flows through some of the Russian and Ukranian territories (James Penn-Larry Allen, Rivers of the World, A Social, Geographical, and Environmental Sourcebook, ABC CLIO, California 2001, p. 65).

${ }^{43}$ Dvina: A river at the northern side of Russia (Penn, ibid, p. 299).

${ }^{44}$ Pietrzak, op. cit., p. 81. 
marriage to Wilhelm was still valid, claimed the act with Jagiełło had to be cancelled. ${ }^{45}$ Documents, related to this issue, disappeared for centuries, are today keeping in the Library of Vatican. According to them the infant betrothal did not mature into a consummated marriage and that Jadwiga had a free conscience to marry Jagiełło. ${ }^{46}$

As soon as they got married, while Jagiełło was endeavouring to convert his people of Lithuania to Catholic faith, Jadwiga took back Red Ruthenia, at the border of south eastern Poland. ${ }^{47}$ On February 14, 1386, the Grand Duke, his brothers, their boyars and nobles, now properly instructed in the Catholic faith, confessed and accepted the true faith and rejected Paganism. ${ }^{48}$ Nevertheless her sister Maria claimed that Red Ruthenia was a Hungarian land. Although this situation involved a collision between the sisters, Jadwiga never forgot that she was the queen of Poland and had to defend her country's interests first. However, circumstances were a bit complicated, as if Maria died childless, Queen Jadwiga of Poland was the heiress to the crown of Hungary. ${ }^{49}$

One of the most remarkable event of her life was her visitation to the Teutonic Knights in 1397. Jagiełło later recognized this when he faced the Teutonic Knights in 1410 at the Battle of Grunwald (Tannenberg). He was grateful that Jadwiga had given him more time, delaying a premature action which would have led to a fatal defeat. ${ }^{50}$ The calumnies that blackening Jadwiga's character about her marriage were all originated by the Teutonic Knights. ${ }^{51}$ At that time a court was held and Jadwiga had to appoint a deputy to defend herself. This evidently shows the importance of the matter and also the negative effects on her. She said: "So long as I live, the Crown will bear your lawlessness with patience. But after my death the punishment of heaven for all the wrongs you have done to Poland shall upon you. War that can not be averted will destroy you". Jadwiga's words came true. Just eleven years later after she died, in 1410, the Polish-Lithuanian armies, led by Jagiello, inflicted a crushing defeat upon the Teutonic Knights at the Battle of Grunwald at Tannenberg, from which it never wholly rallied. ${ }^{52}$

She made great efforts to make her country equivalent in science and education with other countries. Jadwiga realized that in order to strengthen the Polish-Lithuanian Union, mere legalistic arrangements would not suffice. It would be necessary to create a cultural community between the two nations. This is what motivated her and her husband to revive and enlarge the university that had been founded in $1364 .{ }^{53}$ Consequently her contribution for developing the Kraków Academy was so significant (It had been founded in 1364 by Casimir the Great). Her main purpose was to make the young Poles to study at home without being compelled to go abroad to Bolognia, Padua, Oxford, Paris or Florence for what they required. ${ }^{54}$ In those days the universities which owned a faculty of theology were the training schools for the church's preachers, pastors and writers. Therefore they taught not only secular subjects, but the speculative and sacred sciences. The growth of this university and the attachment to it of a

${ }^{45}$ Adam Zamoyski, The Polish Way, A Thousand-Year History of the Poles and Their Culture, John Murray Publihers Ltd., Great Britain 1987, p. 47.

${ }^{46}$ Sluszka, op. cit., p. 173.

${ }^{47}$ Sluszka, ibid, p. 191.

${ }^{48}$ Długosz, op. cit., p. 202.

${ }^{49}$ Sluszka, op. cit., p. 193.

${ }^{50}$ Thaddeus V. Gromada, “Oscar Halecki's Vision of Saint Jadwiga of Anjou”, The Polish Review, Vol. 44, No. 4, University of IIIinois Press, United States of America 1999, p. 436.

${ }^{51}$ Sluszka, op. cit., p. 215.

${ }^{52}$ Sluszka, ibid, p. 219.

${ }^{53}$ Gromada, op. cit., p. 436.

${ }^{54}$ Sluszka, op. cit. p. 229. 
theological faculty, was one of the many projects for the benefit of her country that filled Jadwiga's thoughts. She could not rest until she carried it through. She was busied with putting it into execution when she was taken hence by her death in 1399. Very importantly Jadwiga seems to be one of the first appreciate the beauty and importance of Polish language. It was through her insistence that Polish was used in church services. Also, it was Jadwiga who ordered the translation of the Scriptures into Polish. In this way, and in many other ways, she prepared the way for the Polish Renaissance by introducing the vernacular language. ${ }^{55}$ She bequeathed her jewels, magnificent gems, her clothes which heavy with gold and silver embroidery and precious stones were sold after her death. Half of the sum went to the poor, the other half went towards the maintenance of the University of Kraków. ${ }^{56}$ She told:

"My will is simple: One half of the proceeds of sale of all that I have, jewels, clothes, ornaments, possessions of every kind, I leave to the University of Cracow, and the other half to be divided among the poor". ${ }^{57}$ For that reason its name changed into 'Jagiellonian University'. Today University of Kraków is still known by the name of the dynasty of its benefactors. Nevertheless she never forgot her people of Lithuania. Since Jadwiga considered it urgent that Lithuanians and their neighbours (meaning Ruthenians) should have well-trained, mature clergy, she did not wait for reorganization of Kraków University, which she knew, would take several years. She decided to immediately endow a college for Lithuanians at the University of Prague on July 20, 1397. ${ }^{58}$ After 1397 the university continued to use her bequest. According to Długosz, The original home of the collegium luridicum and the collegium medicum on Grodzka Street Kraków were both established with her bequest. ${ }^{59}$ In 1405 , also a salt mine was bought with it. Its annual income was used for university's needs and in the same year Jagiełło confirmed the mine that belonged to the property of university. ${ }^{60}$

On June 22, 1399 she gave a birth prematurely to a daughter but unfortunately the infant, named Elizabeth Bonifacia, could only live for three weeks and died on July 13, 1399. According to Dlugosz the date of her baby was on June 12, 1399. Jadwiga's physical frame was unable to bear this last and bitter sorrow. Then she fell gravely ill, on day of July 17, 1399 she gave up her soul just four days later, after her baby's death. ${ }^{61}$

Not only was planned consolidation of the Polish-Lithuanian Union carried out according to her intentions in the famous charters of the following years, but it can be shown that she had prepared also most of the other achievements of the opening century. Two hundred years later, a more perfect union was concluded in Lublin in $1569^{62}$ and The Union of Brest ${ }^{63}$ in the same

${ }^{55}$ Gromada, op. cit., p. 436.

${ }^{56}$ Sluszka, op. cit., p. 231

${ }^{57}$ Gromada, op. cit., p. 437.

${ }^{58}$ Gromada, ibid, p. 437.

${ }^{59}$ Dlugosz, op. cit., p. 313.

${ }^{60}$ Paul W. Knoll, "Jadwiga and Education", The Polish Review, Vol. 44, No. 4, University of IIlinois Press, United States of America 1999, p. 429.

${ }^{61}$ Długosz, op. cit., p. 301

${ }^{62}$ Union of Lublin: According to this union, the kingdom of Poland and the Grand Duchy of Lithuania already from one indivisible and uniform body and were not distinct, but composed one common Republic, which had been constituted and formed into one people out of two states and nations. That was a remarkable declaration. The act, written in Polish, not in Latin, used 'państwo', the modern Polish word for state. But its purpose was not to create a union state, but a republic that encompassed two different states and was formed by two different nations coming together into one 'people' that is, a civic nation of citizens that could encompassed separate nations. The Lithuanians had won the argument, and the formula recognized the equal status of esteem they had craved for so long, with all the necessary 
year united Latin and Eastern Christians in the Jagiellonian Commonwealth. A queen of western Christian origin, who brought to the eastern borderlands of Christian Europe a message of peace and increased the chances of a federal system which could be extended to the whole region, even today. ${ }^{64}$

\section{Polish-Lithuanian Union and Their Struggle with the Teutonic Knights}

Since 1362, in less than a hundred year Lithuania got quadrupled its territory in terms of its raids and triumphs. But, because of it consisted mainly Christian Slav population, ordering those lands were not only so difficult, caused Lithuanians confrontation with the Tartars and the Teutons as well. Furthermore, having a longer border to Russian Principalities, Poland attacked to the part of Mazovia ${ }^{65}$ in the Lithuanian lands. When Jagiello ascended to the throne, the situation of country was as mentioned above and Lithuania urgently needed an ally against its opponents. ${ }^{66}$

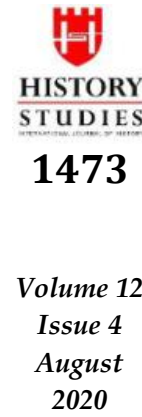

attributes of statehood: Their own government ministers, own army and legal system (Robert Frost, “Unions, Nations ans States: A Historical Perspective”, British Academy, London, Autumn 2017, p. 39).

${ }^{63}$ Union of Brest: It was convoked at Brest, near the Polish- Lithuanian border, in early October 1596. It had two crucial consequences. Firstly, the Ukranian and White Ruthenian population of the commonwealth gradually began to grow in number. They now belonged to the Western community than before although they also attached their Eastern liturgy. And they were not effected from the Muscovite or Ottomans. Secondly, the cultural progress and greater vitality of the Ruthenians was not limited to those who joined the movement but also stimulated those who opposed it. The theological, historic and legal controversy that had been criticised at Brest, contributed to closer intellectual relations between the Ruthenia and the Western world, whether Catholic or Protestant (Oscar Halecki, Borderlands of Western Civilization, A History of East Central Europe, Ed. Andrew L. Simon, Simon Publications, United States of America 1980, p. 208-209).

${ }^{64}$ Gromada, op. cit., p. 437.

${ }^{65}$ Mazovia: Historic geographic lowland region in Poland in the basin of the middle Vistula and lower Bug rivers. The name Mazovia was chronicled for the first time in 1406, The territory became a part of Poland in the tenth century (Lerski, op. cit., p. 344).

${ }^{66}$ Zamoyski, op. cit., p. 42.

${ }^{67}$ Lewinski-Corwin, op. cit., p. 72.

\section{History Studies}




\section{The Teutonic Order}

We have to point out that the main reason of this order's establishment was the desperation of the insufficiency in medical field than deficiency of warriors in 1190 diseases ravaged the Crusaders besieging Acre ${ }^{68}$ (Crusaders conquering Acre were ravaged by diseases in the year of 1190). Because conditions were not sufficient and also unfortunately the soldiers, came from Northern Europe, were not accustomed to heat, water, food or sanitary conditions. The resident and regular hospitals were overburdened. ${ }^{69}$

This situation was not tolerable. So some middle-classed crusaders, came from Bremen and Lübeck, decided to found a hospital for taking cares of their German patients. Consequently a new hospital, named Order of the Hospital of St Mary of the Germans in Jerusalem was founded. It was like St Jean's (Hospitallers) hospital in working and like Templar Knights' in continuing. That hospital was not only cured the patients, but also supplied food, accommodation and money to Germans who had just arrived to Acre. Germans in Acre requested Pope Celestine to approve their decision about their hospital order for providing garrisons to some frontier castles. ${ }^{70}$ The Pope, by accepting their request, issued a new charter in 1198. Consequently the English-speaking world named this order 'The Teutonic Knights'. Those knights', whose a big part of them belonged poor and noble families of West and Central Germany, except for Prussia borning ${ }^{72}$ ones, missions were to fight, treat the patients and convert infidels to Christian faith. In 1260 they believed that their sins were forgiven just by joining to the crusade. ${ }^{73}$

The army mentioned above consisted of both mercenaries and volunteers was so strong and equipped to the extent that it was not in any European country before the $1400 \mathrm{~s} .{ }^{74}$ The Teutonic Order who had an expansionist policy collided with Poland and Lithuania. The latter was most threatened, for the Order state sought to conquer the Baltic coast and might have considered inland as well. Order's disagreement with Poland was on controlling the territories that once belonged to Poland crown, particularly the valuable port of Gdańsk. The Teutonic Order supported their territorial claims in European public opinion with both Jagiello's and Lithuania's choice about their Christian faiths. Even they made a requirement to the Papacy court related to their sincerity with the helpings of Luxembourg and Hungarian kings.

In early modern Europe, Poland-Lithuania, before the Union of Lublin, was an example of a composite monarchy. According to this kind of administration rulers did not completely remove the local institutions of their component territories and often allowed local elites for governing their own subjects, provided that they accepted the superior authority of the

\footnotetext{
${ }^{68}$ Acre: The city of Acre on the Syrian coast was once a famous Crusader stronghold. In the centuries following the Crusades the city had slipped into oblivion and by the time of the Ottoman conquest, Acre, was a collection of ruins in which only a few Arab fishermen found shelter. But in the eighteenth century Acre witnessed a dramatic rise in its fortunes, making in 1785 the third largest city in Syria -after Aleppo and Damascus- and the largest part on the Syrian coast (Thomas Philipp, Acre, The Rise and Fall of a Palestinian City 1730-1831, Columbia University Press, New York 2001, p. 1).

${ }^{69}$ William Urban, The Teutonic Knights, A Millitary History, Greenhill Books London, Stackpole Books Pennsylvania, p. 11.

${ }^{70}$ Urban, ibid, p. 12.

${ }^{71}$ Urban, ibid, p. 13.

${ }^{72}$ Stone, op. cit., p. 16.

73 Stephen Turnbull, Tannenberg 1410, Disaster for the Teutonic Knights, Campaign 122, Osprey Publishing. P. 14, 2003.

${ }^{74}$ Stone, op. cit., p. 15.
} 
monarch. ${ }^{75}$ Furthermore the most important point before Lublin Union, the two countries separately organised their Diet ${ }^{76}$. After this agreement between them, this was changed that the nobility of Poland and Lithuania elected their monarchs by common royal election and convened the Diet together. ${ }^{77}$

To this Union, each country could keep its own treasury and army. The public office hierarchy organization belonged to Lithuania and Poland separately. The Polish-Lithuanian Commonwealth, was formed through the Union of Lublin, became a polity which might be called a 'composite monarchy', as the throne was elective and to a large extent the royal prerogative was restricted by the privileges of the elites. ${ }^{78}$

When the Union is evaluated in terms of Poland, the first noticeable point was the three-fold expansion of its lands that it could not easily manage. However, all this wealth was spent for the ambitions of the Union, which caused Poland to collapse after 400 years. On the other hand, it is an undeniable fact that the Union has great powers of Europe thanks to this unity that was a definite victory against the Teutonic Knights. Thus, the land dreams of Poland became true; by the end of the fifteenth century it had ruled one third of the European territory from the Baltic Sea to the Black Sea and the Adriatic shores. Unfortunately, Poland was unable to maintain this power and in sixteenth century it lost most of its kingdoms outside of the Polish territory to Habsburg. ${ }^{79}$

Lithuania, on the other hand, recognized the Roman Church as a result of the union between the two countries, thereby becoming a member of the family of western countries. In addition, Lithuania, which had focused all its attention on the struggles with Crusaders; it also got back a big part of its lands that had been lost related to its union with Poland.$^{80}$ The wars between the Teutonic Knights and the union continued through fifteenth century, though Lithuanians converted Christianity. The main reason for this dispute was the corporation with Lithuania and it changed the balance of power in Eastern Europe. ${ }^{81}$ The Teutonic Order stated that the conversion of the Lithuanian people was merely an imitation, by liking them to Saracens and thereby the Order supported her ex-finance's country, Habsburg. ${ }^{82}$ The Teutonic Knights did not recover after their defeat against Poland between 1409-1411 (Battle of GrunwaldTannenberg); this devastating hostility continued for another 55 years albeit on a small scale. ${ }^{83}$

75 Satoshi Koyama, "The Polish-Lithuanian Commonwealth as a Political Space: Its Unity and Complexity", Grants-in-Aid for Scientific Research program of the Japan Society for the Promotion of Science in 2005-2007, Japan 2005, p. 138.

${ }^{76}$ Diet: Polish Diet from becoming a deliberative assembly like, say, the House of Commons of the day. Because of the former, it was improbable that any decision could be taken; because of the latter, minds were (Jean Jacques Rousseau, The Government of Poland, Hackett Publishing Company, Indianapolis 1985, p. XXI). Another explanation is, the Polish Diet, a noble assembly, confirmed or rejected all major decisions of the king affecting the kingdom. Moreover, every member of the Diet had a particularly precious right, the liberium veto. Should any member wish to stop debate on an issue before the Diet and dissolve it, he could do so by simply announcing his veto of proceedings (Michael Burger, The Shaping of Western Civilization from the Reformation to the Present, Vol.II, University of Toronto Press, Toronto 2014, p. 295).

${ }^{77}$ Koyama, op. cit., p. 138.

${ }^{78}$ Koyama, ibid, p. 139.

${ }^{79}$ Zamoyski, op. cit., p. 50.

${ }^{80}$ Lewinski-Corwin, op. cit., p. 78.

${ }^{81}$ Turnbull, op. cit., p. 17

${ }^{82}$ Turnbull, ibid, p. 18.

${ }^{83}$ Stone, op. cit., p. 17. 


\section{Jadwiga the Queen in the American Press of Twentieth Century}

Primarily, if a queen, who had lived in fourteenth century, was always mentioned in any news -all of them did not directly about her- related to Poland has to be interpreted as an evidence of her identification with her country. Although she died in 1399, we came across her name between the years of 1915-1945 in American press. One of them was about a Polish art exhibition that was held in 1922 at Washington. There were also exhibited Poland's outstanding painter Jan Matejko's ${ }^{84}$ masterpieces including a Jadwiga's ${ }^{85}$ portrait. ${ }^{86}$
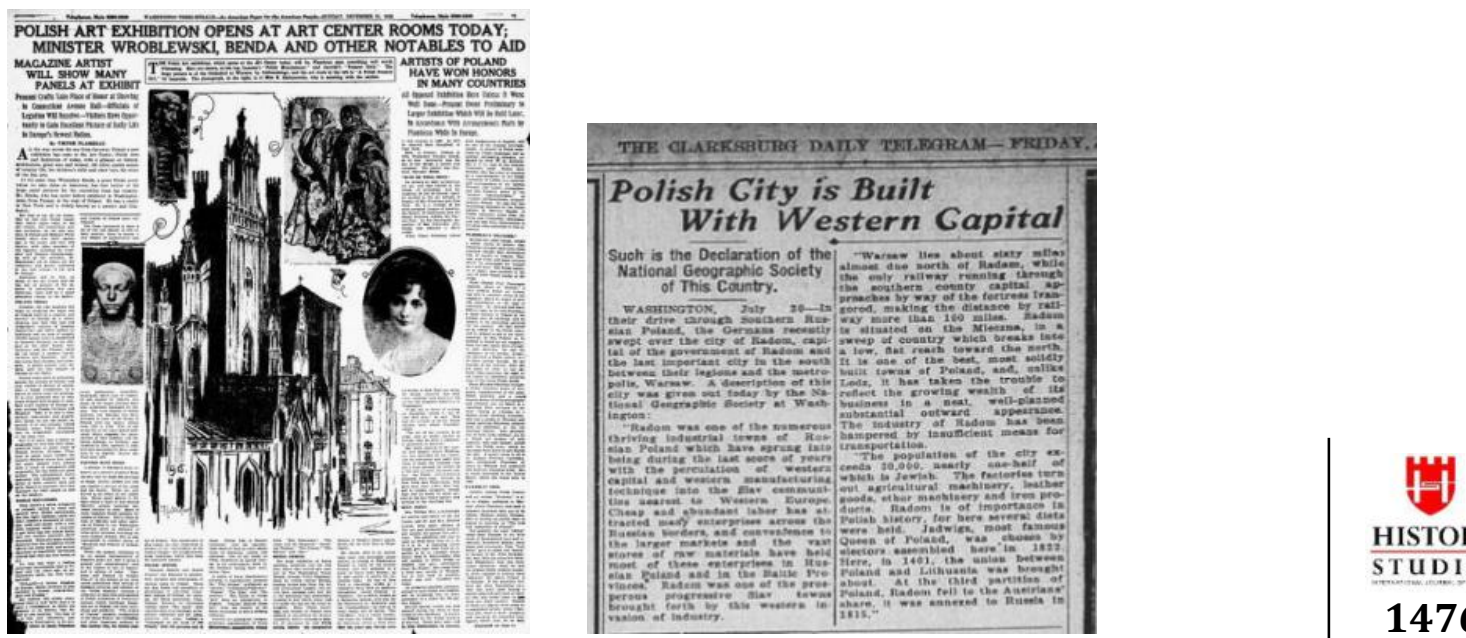

HISTORY

STUDIES

Another news was about German troops' entrance to city of Radom in the Russian part of Poland in 1915. The National Geographic Society at Washington, by giving a description of this city's geography, Population, etc., pointed out the importance of it as Jadwiga was chosen by electors assembled there in $1382 .{ }^{87}$

An advertisement of the year 1945 for Christmas was so interesting. At this, besides the good wishes, there was a clause that comprise a word of 'peace' was identified with Jadwiga: "Peace on Earth, Inspired and universal the Queen Jadwiga was. ${ }^{88}$

\footnotetext{
${ }^{84}$ Jan Matejko (1838-1893): Poland's most famous painter during the nineteenth century. Matejko is particularly celebrated for his enormous patriotic represantations of Polish history, such as The Battle of Grunwald and the Prussian Homage, George Sanford,, Historical Dictionary of Poland, European Historical Dictionaries, No. 41, The Scarecrow Press, Inc., Oxford, 2003, p. 116.

85 At the opening of Queen Jadwiga's grave for restoration work in 1891, from the remains in the sarcophagus, Jan Matejko was there and noted the following elements of Jadwiga's beauty: "Queen Jadwiga was of radiant loveliness. She was tall, had a longish face, oval head and a straight narrow but thin nose, and a wide firm mouth", Sluszka, op. cit., p. 65.

${ }^{86}$ Viktor Flambeau, "Polish Art Exhibition Opens at Art Center Rooms Today; Minister Wroblewski, Benda and Other Notables to Aid", The Washington Times, December 31, 1922, p. 5.

87 "Polish City is Built with Western Capital", The Clarksburg Daily Telegram, July 30, 1915, p.8.

88 "Peace on Earth, Inspired by the Queen Jadwiga of Poland", Marion Progress, December 20, 1945.
} 

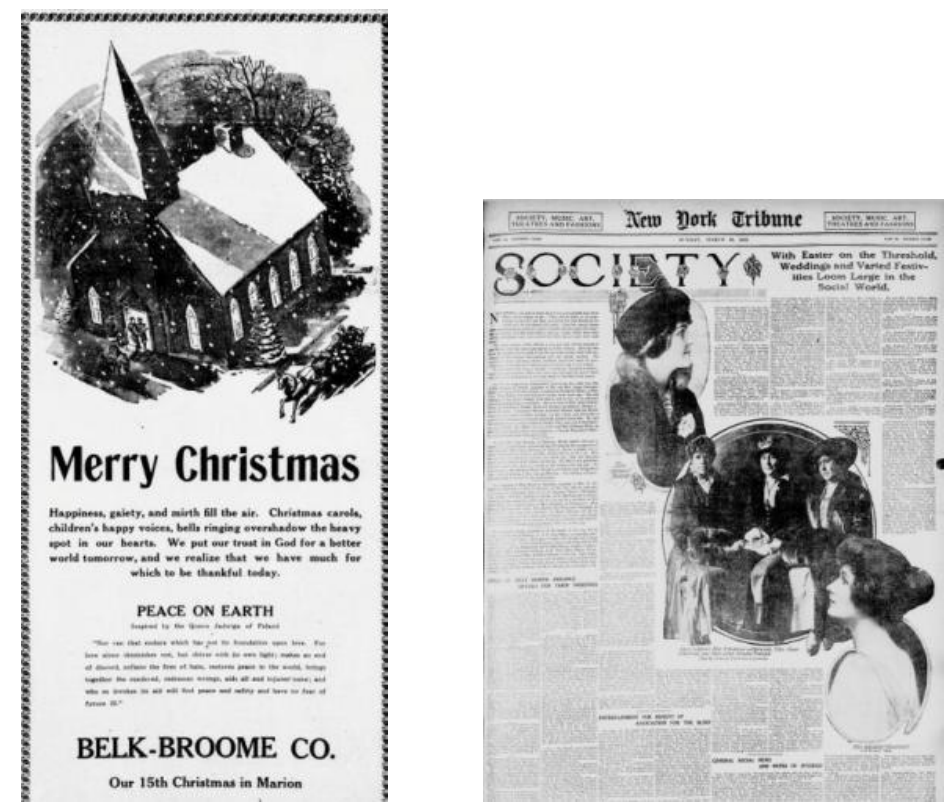

Another one was about an entertainment that was held on April 6, 1915 by New York Association for the Blind. There, a theatre about Jadwiga's life had taken a stage. While Queen was impersoned by Mary Pyle, her husband was by Lawrence Butler. But the remarkable point in that news was concerning Jagiełło that he was named as 'King Jadwiga'. ${ }^{89}$

There are a lot of news about her at the Library of Congress' digital archive, but we have used only these ones. Eventually we have seen an information related to an American writer Charlotte Kellogg's book about Jadwiga. Her life was closely described so that it is a valuable kind of source of her. Furthermore the most considerable point is the introduction Jadwiga to Americans, who was declared as a 'saint' by her people. ${ }^{90}$ This book was also reported in 1936 again. $^{91}$

\footnotetext{
89 "Entertainment for Benefit Association for the Blind", The New York Tribune, 28 March, 1915, p. 7.

${ }^{90}$ Ida Gilbert Myers, "Reviews of the New Books", The Evening Star, November 29, 1931, p. 15.

${ }^{91}$ Mary Carter Roberts, "Masefield Volume Among Week's Varied Books”, The Evening Star, June 20, 1936.
} 


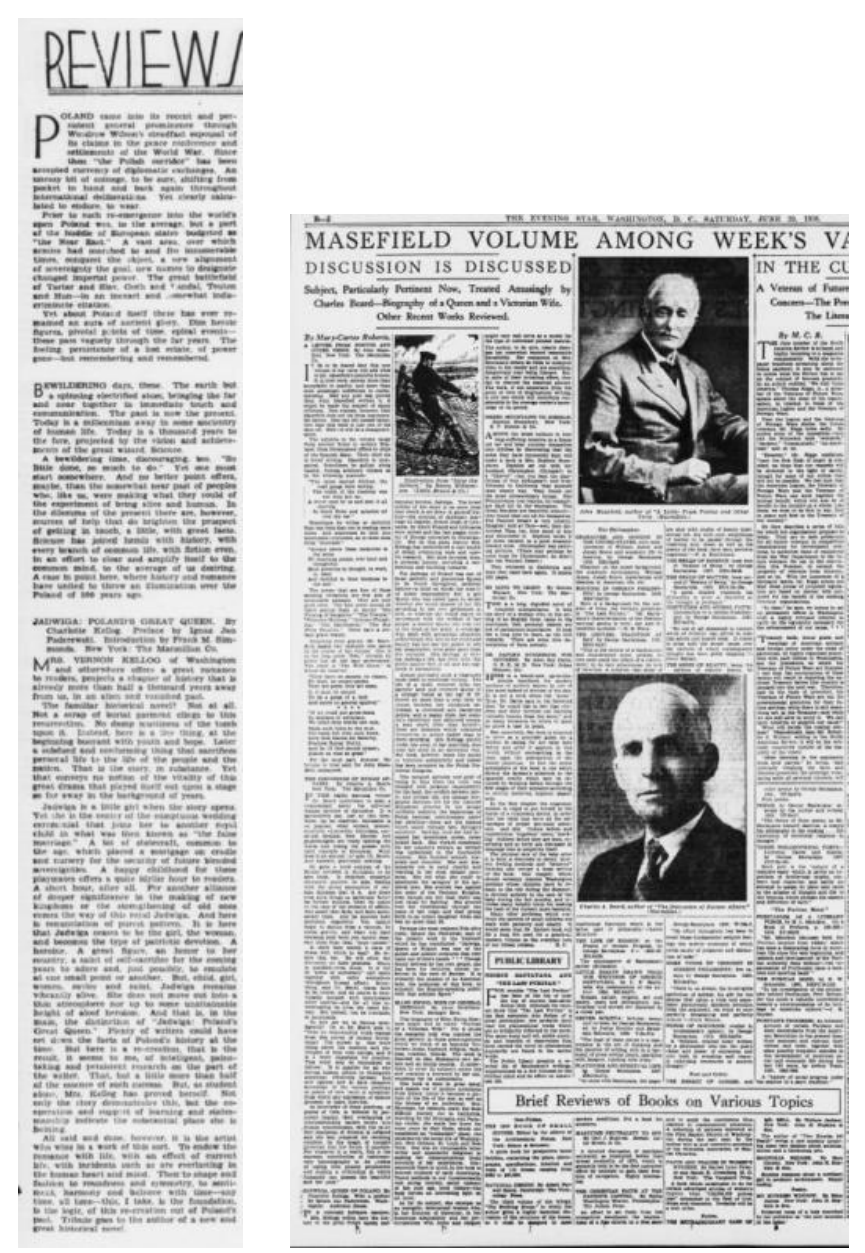

\section{Conclusion}

The idea of this union with Lithuania was firstly came up in fourteenth century and the foundation of the union was laid with marriage between Jagiełł, the Grand Duke of Lithuania and Jadwiga, the Queen of Poland in terms of both countries, it can be said that it has many benefits. The most important of them was the power that gained against The Teutonic nights and thereby Poland had become the largest country all over Europe by reaching its fivefold territory in measurement. Although the Teutonic Knights were once established for positive and useful purposes, in times by serving the imperialist ambitions of the German Empire, they became a threat against Poland and Lithuania. As a result of the Battle of Grunwald, one of the most noticeable battle of the medieval age, which was held in 1410-1411 with the Teutonic Knights, the powerful Teutonic regime suffered an unbeatable defeat.

Queen Jadwiga's death in 1399, who devoted herself to Christianity, education and civilization of Poland; was also proved her devotion to her country in the absence of her husband Jagiełło by fighting against the Hungarians, who encircled the Polish border despite they were her citizens, was a great loss. That was because, Jagiełło constantly transferred some regional revenues and Jadwiga donated all her jewels, the name of the Kraków Academy was changed into Jagiellonian University due to the couple's contributions. 


\section{Bibliography}

BURGER, Michael, The Shaping of Western Civilization from the Reformation to the Present, Vol.II, University of Toronto Press, Toronto 2014.

DAVIES, Norman, God's Playground, A History of Poland, The Origins to 1795, Vol. I, Columbia University Press, New York 2005.

DŁUGOSZ, Jan, Roczniki Czyli Kroniki Sławnego Królestwa Polskiego 1370-1405, Księga 10, Wydawnictwo Naukowe Pwn, Warszawa 2009.

FROST, Robert, "Unions, Nations and States: A Historical Perspective", British Academy, Autumn, United Kingdom 2017, pp. 36-41.

GROMADA, Thaddeus V., "Oscar Halecki's Vision of Saint Jadwiga of Anjou", The Polish Review, Vol. 44, Nr. 4, University of IIIinois Press, United States of America 1999, pp. 433-437.

HALECKI, Oscar, Borderlands of Western Civilization, A History of East Central Europe, Ed. Andrew L. Simon, Simon Publications, United States of America 1980.

KELLOGG, Charlottte, Jadwiga, Poland's Great Queen, Borodino Books, 2018.

KNOLL, Paul K., "Jadwiga and Education", The Polish Review, Vol. 44, No, 4, university of IIIinois Press, United States of America 1999, pp. 419-432.

KOYAMA, Satoshi, "The Polish-Lithuanian Commonwealth as a Political Space: Its Unity and Complexity", Grants-in-Aid for Scientific Research program of the Japan Society for the Promotion of Science in 2005-2007, Japan 2005, pp. 137-153.

LERSKI, George J. , Historical Dictionary of Poland 966-1945, Greenwood Publishing Group, Ed. Piotr Wróbel-Richard J. Kozicki, London 1996.

LEWINSKI-CORWIN, Edward H. , The Political History of Poland phD, The Polish Book Importing Company, New York, 1917.

MILLS, Lois, So Young Queen Jadwiga of Poland, Bethlehem Books, Ignatius Press, Bathgate Lothrop, Lee and Shepard Co., Inc. ,1965.

NIELSEN, Hans Frede, From Dialect to Standard: English in England 1154-1776, University Press of Southern Denmark, Denmark 2005.

PENN, James-Larry Allen, Rivers of the World, A Social, Geographical, and Environmental Sourcebook, ABC CLIO, California 2001.

PHILIPP, Thomas, Acre, The Rise and Fall of a Palestinian City 1730-1831, Columbia University Press, New York 2001.

PIETRZAK, Anna Kowalska, "History of Poland During the Middle Ages", Institute of History University of Łódź, Poland 2015, pp. 61-93.

PRESTWICH, Michael, Plantagenet England 1225-1360, Oxford University Press, New York 2005.

ROBERTS, Nigel, Belarus, Bradt Travel Guides Ltd., England 2011.

ROUSSEAU, Jean Jacques, The Government of Poland, Hackett Publishing Company, Indianapolis 1985. 
ROWELL, S. C. , "1386: "The Marriage of Jogaila and Jadwiga Embodies, The Union of Lithuania and Poland", Lithuanian Historical Studies, Source Publications, Lithuania 2006, pp. 137-144.

SANFORD, George, Historical Dictionary of Poland, European Historical Dictionaries, No. 41, The Scarecrow Press, Inc., Oxford, 2003.

SCHOLZ, Albert, Silesia Yesterday and Today, Springer-Science, Business and Media B. V. , Netherlans, 1964.

SLUSZKA, Sigismund John, Queen Jadwiga in History and Legend, phD Thesis, The Faculty of Arts of the University of Ottawa, Canada 1950.

STONE, Daniel, The Polish-Lithuanian State, 1386-1795, A History of East Central Europe, Vol. IV, University of Washington Press, Seattle \& London 2001.

TURNBULL, Stephen, Tannenberg 1410, Disaster for the Teutonic Knights, Campaign 122, Osprey Publishing, 2003.

The Ukranian Quarterly, Vol. 5, Ukranian Congress Committee of America, United States of America 1949.

URBAN, William, The Teutonic Knights, A Military History, Greenhill Books London, Stackpole Books Pennsylvania 2003.

ZAMOYSKI, Adam, The Polish Way, A Thousand-Year History of the Poles and Their Culture, John Murray Publishers Ltd. Great Britain 1987.

\section{Newspapers}

"Entertainment for Benefit Association for the Blind", The New York Tribune, 28 March, 1915.

FLAMBEAU, Viktor, "Polish Art Exhibition Opens at Art Center Rooms Today; Minister Wroblewski, Benda and Other Notables to Aid", The Washington Times, December 31, 1922.

MYERS, Ida Gilbert, "Review of the New Books”, The Evening Star, November 29, 1931.

"Peace on Earth, Inspired by the Queen Jadwiga of Poland", Marion Progress, December 20, 1945.

"Polish City is Built with Western Capital", The Clarksburg Daily Telegram, July 30, 1915

ROBERTS, Mary Carter, "Masefield Volume Among Week's Varied Books", The Evening Star, June 20, 1936.

\section{Internet Sources}

http://www.loc.gov (A.D. 02.05.2020) 